\title{
MARKET REACTION ON EXECUTIVE OPTION GR ANT IN THE EXISTENCE OF PERFormance HuRdLeS
}

\author{
Yuniarti Hidayah Suyoso Putra \\ Fakultas Ekonomi Universitas Islam Negeri Maulana Malik Ibrahim Malang \\ J1. Gajayana No. 50, Telepon (0341) 558881, Fax. (0341) 558881, \\ Yuniarti_hidayah@yahoo.com
}

\begin{abstract}
Abstrak
Penelitian ini bertujuan untuk menginvestigasi reaksi pasar terhadap pengumuman opsi kepada eksekutif. Pasar bereaksi positif jika mengganggap pemberian opsi sebagai berita yang mengguntungkan karena pemberian opsi akan memotivasi eksekutif dalam memperjuangkan kepentingan pemegang saham dan bekerja lebih giat dalam meningatkan kinerja perusahaan. Reaksi negatif pasar menunjukkan bahwa pemberian opsi akan meningkatkan biaya agensi dan mengurangi kekayaan pemegang saham. Hasil penelitian menunjukkan bahwa pasar berekasi positif dan menganggap pengumuman pemberian opsi kepada eksekutif sebagai berita yang menguntungkan. Hasil penelitian juga menunjukkan 'performance hurdle' melekat pada sebagaian besar eksekutif opsi di Australia sehingga pasar yakin eksekutif tidak bisa menggunakan hak opsinya secara maksimal jika syarat kinerja belum terpenuhi.
\end{abstract}

Key Words: Opsi saham, Eksekutif, Reaksi Pasar, Performance Hurdles

The dramatic increase of the use of share option as a part of compensation package to executive indicates it has become a popular means of compensating employees. More than $50 \%$ of the S\&P 500 firms granting executive with share option by the end of 1990s in US. Meanwhile, in Australia, long-term incentives, such as share options represent on average of 17 per cent of the total CEO's compensation at the 2005 Annual General Meetings (Buffini and Kitney, 2005). About 40 out of the top 100 companies sought approval from shareholders to issue options to executive directors as a component of long-term incentives packages at the 2005 Annual General Meeting (Hooper, 2005). The reason is the grant may be encouraged CEO to achieve good performance in the future.

However, share option grants to executive can be controversial. Shareholders are concerned with the effectiveness of share options in aligning manager-shareholders interest. Therefore, it is important to investigate how the market responds to the announcement of executive option grants. Such an 
investigation will provide insights into the markets' perception of the benefit of option grants.

Noticeably, Australian studies of executive share option grants have focused on firm-specific characteristics associated with the existence of executive share option plans (e.g., Coulton and Taylor, 2002; Goodwin and Kent, 2004), the appropriate model to value executive share option grants (e.g., Bergmann, 2003; Cassano, 2003; Brown and Yew, 2002; Brown and Samson, 2003; Kerin, 2003; and Clark 2004). Studies related to the alternative accounting treatment for executive share option (e.g., Stoddart, 2001), and the disclosure of CEO compensation (e.g. Chalmers and Koh, 2005). To my knowledge, no Australian study has investigated the market reaction associated with the announcement of executive share option grants.

This study investigates market reaction around the announcement of executive option grants with performance hurdles to be satisfied as a pre condition to vesting.

\section{THE ROLE OF SHARE OPTION GRANT}

Share option grants aimed to align executive and shareholders interests. The grants will give the executive incentives to act in his best in achieving the company's performance. The inclusion of share options as a component of compensation might retain potential executives. Hall and Murphy (2002) underline the objectives of share options are to attract, retain, and motivate executives and other employees. Share options help the company to attract high skilled executives and relatively less-risk averse since these individuals naturally will select the companies offering performance based compensations that have potential benefits for them. Share options provide retention through a combination of vesting provisions and long-term options and motivate the executives in terms of providing a direct link between company's performance and executive wealth. Share options can used to reward past performance and promote future performance.

Hutchinson (2003) investigates the association between firm risk, executive share options and accounting performance. The study from 182 
Australian firms from 1998 to 1999 indicates that executives who have an investment in the firm in form of share options rather than shares adopt high risk-return projects and the strategy to increase firm's value. The negative relationship between risk and firm performance is weaker when executives hold more share options than shares. The result indicates that share option can align the interest between the agent and principal, reduce the agency costs, and avoiding risk-averse behaviour.

\section{MARKET REACTION TO OPTION GRANT}

The Efficient Market Hypothesis (EMH) theory explains that market will react to new unanticipated information. The reaction will reflect in price movements and trading volume changes around the date and time of the information release. If markets consider the new information as favourable news and the information is unexpected, share prices and trading volumes will increase. On the other hand, if the market believes that the information to be unanticipated unfavourable news, a decrease in share prices and trading volumes is expected.

The perception of favourable news and unfavourable news can relate to the markets ability to obtain private information. If traders could not obtain private information of a public announcement prior to the announcement, there would be a temporarily high degree of trading volume and information asymmetry, until traders incorporate the news during the trading process. Furthermore, if it is assumed that traders could obtain private information, form opinions, and trade before public announcement, then they will update their expectation prior to the announcement (Nofsinger and Prucyik, 2003), consistent with efficient market hypothesis that all information should be fully incorporated in the share prices.

Finding from Morgan and Poulsen (2001) showed a positive reaction for the compensation plan (including share option plans, restricted share plans, performance plans) particularly targeting top executives, because it delivers favourable signals of future performance. The positive reactions reveals new information to the market that managers expect the company's performance will 
increase and are willing to tie their compensation schemes to the company's performance.

Whilst, Brickley, Bhagat and Lease (1985) discovered a positive share price reaction to the announcement of long-term managerial compensation schemes proposed by the board of directors of the firms and presented to shareholders for ratification. The two days cumulative abnormal return shows that these managerial compensation schemes can increase shareholders wealth. However, the results do not prohibit the possibility that a sharing of tax benefits with managers in tax-motivated plans could derive the benefits to shareholders. There is a possibility that the model specified incorrectly; hence, the positive cumulative abnormal return might be due to the error in benchmark rather than the favourable market reaction. The analysis of variance of this study shows that there is also no difference in the market reaction across different types of compensation plans (e.g. share options, performance plans, and restricted shares) supporting the perception that different type of plans may be suitable in different situations.

However, there is also negative market reaction related to options proposals that have high potential dilution effect on shareholders wealth. Martin and Thomas (2003) documented significant negative cumulative abnormal return in three days around the announcement of executive share option plans only. They also reported that the plans that include repricing provisions, permit the executives to borrow money from the firm in order to exercise options or plans that permit the issues of restricted shares do not experience significant negative return, because it depended on the magnitude of voting against the plans with these features.

Lie (2005) also found negative abnormal returns of $-3 \%$ for 30 days before the announcement of CEO grants. The negative abnormal return mostly occurred 10 days before the grant date for unscheduled CEO option grants. A positive abnormal return of $2 \%$ occurred for the first 10 days after the announcement date and almost another $2 \%$ for the next 20 days. Unscheduled share option grants denote to the share options are not granted on the same date every year. Therefore, the CEO might use their influence to set the grant date when the share prices are particularly low. The results indicated that executives might time the 
grants at the date when the share prices are particularly low, thus securing a lower exercise price. The presence of abnormal return around the announcement dates indicates that information currently incorporated in the share prices. Hence, this situation might lead to the opportunistic behaviour from the executives such as CEO to obtain future benefits by timing the release of the news.

\section{PERFORMANCE HURDLES}

Despite of the benefit and market reaction to executive share options, a controversial issue arises at annual general meetings is inadequacy of the performance hurdles attached to the option grant. For example, the Australian Shareholders Association (ASA) raised this issue at the Seven Network annual general meeting and argued that the company set too low hurdles for the executive option grant (Kavanagh, 2003). Setting of easily achievable hurdles may influence to the dilution effect on shareholders wealth. Another case, the board of the National Australia Bank criticized for the terms attached to CEO option grants. The CEO of National Bank Australia was rewarded with 500,000 options that would vest after three year if the banks' total shareholders return (TSR) was between the top quartile in its peer group. Twenty five percent of options would vest if the bank's TSR were in third quartile. It means that CEO would be rewarded the grants for delivering a TSR, below the median of its peer group (Kavanagh, 2001).

Colquhoun (2001) explains adequate performance hurdles attached to options grants will encourage the executives to earn this compensation component by considering the achievement of company's objectives more carefully. It also will increase investors' confidence that this compensation package is aligned with shareholders interests. Performance hurdles ensure the shareholders that the CEO or other executives are only rewarded if they achieve a good performance that has positive payoffs for shareholders. Well design performance hurdles should ensure that the CEO would only receive the grants if he or she performs better than the competitors (Lawson, 2004). For example, John Fletcher-Coles Myers' CEO and Myer boss Dawn Robertson got a pay cut in after failing to achieve key performance hurdles in 2004-2005 The pay cut decreased 
Mr Fletcher's total remuneration from \$5.34 million in 2004 to \$4.43 million and Ms Robertson's total pay decreased from \$3.3 million to \$2.7 million (Leyden, 2005).

Performance hurdles can be market based on firm specific. Common hurdles include Total Shareholder Return (TSR) as measurement function of share-price growth plus dividend growth, Earning Per Share (EPS) growth, Return on Investment (ROI), Return on Invested Capital (ROIC), increase in revenue, and increase in net profit (Rappaport, 1999; Kavanagh, 2001, Ernst and Young, 2003).

\section{HYPHOTESIS DEVELOPMENT}

The hypotheses are developed and predicted market reaction around the announcement dates of executive option grants.

\section{Alignment Hypothesis}

The agency theory predicts that compensation schemes will be designed to stimulate executive to make decisions consistent in increasing shareholders wealth and reducing agency costs (Jensen and Murphy, 1990; Grinner, 1999). It is expected that the granting of share options as a part of compensation packages can reduce the agency cost resulting from agency problems, which exists in manager-shareholders relationships and linking between the pay and the company's performance (Morgan and Poulsen, 2001).

The establishment of share options as the part of compensation might be employed to retain potential executives. The achievement of performance target and vesting periods created in the contract will restrict executive to exercise the options and therefore it ensures his loyalty to the company (Goodwin and Kent, 2004). Market expects that granting options will encourage executive to act in shareholders' best interest, implying that the market believes such grants can reduce the agency costs from improved incentives, signals favourable future performance and shared taxation benefits (Brookfield and Ormrod, 2000). It implies that granting executive options may give the incentives to take more risk and can play an important role to reduce agency cost of equity.

Furthermore, the positive market reaction is likely to occur based on the argument that market perceives the granting of executive with share options 
attempts to deliver a favourable news rather than unfavourable news (Yermack, 1997; Nofsinger and Prucyk, 2003). The investors are confidence that executives who are being granted with such compensation packages are financially motivated to increase shareholders wealth (Colquhoun, 2001; Thompson, 2002). This confidence could be the key driver in increasing share price. Alternatively, if market considers the announcement of executive option grants convey unfavourable news negative abnormal returns are predicted. Thus, it has likelihood to dilute shareholders wealth and cannot improve the company's performance.

The positive assumption is consistent with the purpose of why firms decide to grant executive with share options. To test how market reacts to the announcement of executive option grants, the following hypothesis is presented.

H1: Firms that announce executive option grants will experience positive abnormal return around the announcement date.

\section{The Performance Hurdles Hypothes is}

Many remuneration consultants say that the size of options packages should come second after consideration as to whether adequate performance hurdles are attached to the options (Kavanagh, 2001). Rappaport (1999) states that the concern associated with the dilution effect of shareholders wealth should not focus on the number of options granted but rather on the number of options that can be exercised in the absence of superior performance hurdles.

Adequate performance hurdles attached to options grants will encourage the executives to earn this compensation component by considering the achievement of company's objectives more carefully (Colquhoun, 2001). It also will increase investors' confidence that this compensation package is aligned with shareholders interests. Performance hurdles ensure the shareholders that the executives are only rewarded if they achieve a good performance that has positive payoffs for shareholders or if he or she performs better than the competitors (Lawson, 2004). For example, John Fletcher-Coles Myers' CEO and Myer boss Dawn Robertson got a pay cut in after failing to achieve key performance hurdles in 2004-2005 The pay cut decreased Mr Fletcher's total 
remuneration from $\$ 5.34$ million in 2004 to $\$ 4.43$ million and Ms Robertson's total pay decreased from $\$ 3.3$ million to $\$ 2.7$ million (Leyden, 2005).

Those arguments denote that the existence of performance hurdles is essential to protect the shareholders wealth, ensure the achievement of company's performance, and reward the CEO appropriately based on his/her performance. Therefore, the following hypothesis is proposed.

H2: The positive market reactions around the announcement of executive option grants are more likely supported with the existence of performance hurdles attached to the grants

\section{RESEARCH DESIGN}

\section{Data Description}

This study investigates the market reaction to the announcement of executive option grants during 1998 to 2004 in Australia. The disclosures of executive and director compensations facilitate the availability of data to test the market reaction to the announcement of executive share option grants. Data is collected from four main databases: Aspect Fin Analysis, Connect 4, IRESS and DataStream.

\section{Sample Selection}

An initial sample of firms granting share option grants exclusive to executive for ASX 500 listed companies during 1998 to 2004 is obtained from Aspect Fin Analysis database. During the process, trust companies were removed from the sample since it is subject to different reporting requirements. This process reduces the sample into 189 executive share option grants announced by 130 companies. Then the final samples are segregated into twogroups: pure executive option grants announcements (92 samples) and executive option grants announced simultaneously with the increase in directors' fees (38 samples). The primary focus of this study is pure executive option grants group. However, investigating the market reaction of executive option grants with the increase in directors' fees facilitate a comparison of how sensitive the market reaction is to concurrent announcement of salary increase. 
Furthermore, information disclosed in notice of annual general meeting, director reports, notes of financial reports, appendix 3B and or ASX released news are utilized to determine and verify the number of share option granted, the exercise price, total number of Executive shares holding, and the existence of performance hurdles.

\section{Event Study Methodology}

Event study methodology is used to examine the impact of executive option grant announcements on the company's share price.

\section{Event Date}

Event date explains the proxy of announcement date employed to benchmark the market reaction. According to ASX listing rule 10.14, the directors' remuneration including executive option grant must be approved by shareholders at the annual general meeting. Based on this reason, the Annual General Meeting date is selected as an event date.

\section{Event Windows}

Event windows section specifies the event parameters and market proxy, abnormal return generation, actual return generation, and the market model used in this study. This section aimed to indicate event parameters and highlight the market proxy. In this study, the Australian All Ordinary Share Price Index is used as the market proxy. The estimation period for this study commences 260 days prior the announcement date of executive option grants (that is the date of annual general meeting) and ends 60 days after the announcement of executive option grants. Meanwhile, the event window is focused on three days around the announcement date (day -1 to day +1$)$.

\section{Abnormal Return Generation}

Abnormal returns (actual returns minus expected returns) are calculated for a specified period around the announcement dates to examine the impact of executive option grant announcements. The abnormal return formula is given in the model 1.

$$
A R=R_{j t}-E\left(R_{j t}\right)
$$


Where

AR = abnormal return for the event $j$ on time $t$

Rjt $=$ observed return for the event $j$ on time $t$

$\mathbf{E}(\mathbf{R} \mathbf{j t})=$ expected return for event $j$ on time $t$

\section{Actual Return}

Actual returns are calculated in continuous form based on daily share price returns (Strong, 1992) using model 2:

$\left.\mathbf{R}_{\mathrm{jt}}=\operatorname{Ln}\left(\mathbf{P}_{\mathrm{jt}}+\mathrm{D}\right) / \mathbf{P}_{\mathrm{jt}-1}\right)$

(Model 2)

Where

$\mathbf{R}_{\mathbf{j t}} \quad=$ actual return on share $\mathrm{j}$ on day $\mathrm{t} ;$

$\mathbf{P}_{\mathbf{j t}} \quad=$ price of share $\mathrm{j}$ on day $\mathrm{t}$;

$\mathbf{P}_{\mathrm{j} t \mathbf{1}} \quad=$ price of share $\mathrm{j}$ on day $\mathrm{t}-1$;

Ln = natural logarithm operator;

D = dividends paid on the day $\mathrm{t}$

\section{The Market Model}

The Market Model will be used in the analysis to calculate expected return. General formula of the market model is as follows.

$R_{j t}=\alpha_{j}+\beta_{j} R_{m t}+\varepsilon_{j t}$

(Model 3)

Where

$\mathbf{R}_{\mathbf{j t}} \quad=$ observed return for even $\mathrm{j}$ on time $\mathrm{t}$

$\alpha_{j} \quad=$ the constant (or intercept) of the model

$\beta_{j} \quad=$ the beta of security $j$

$\mathbf{R}_{\mathrm{mt}} \quad=$ observed return on market index on time $\mathrm{t}$

$\varepsilon_{\mathrm{jt}} \quad=$ error term

\section{Statistical Testing}

The use of these two statistical tests improves the robustness of the study.

\section{Parametric Test}

The examination of statistical significance of abnormal returns requires the calculation of a t-statistic. This parametric test assumes the normal distribution of abnormal returns. However, even though the parametric test is more powerful than non-parametric, this test is not problems' free. 


\section{Standardised Cross Sectional T-test (SCST)}

This study used standardized cross sectional t-test (SCST). This test involves calculating average abnormal returns for event period and standardizes it by standard error of the regression of the market model. SCST is used to overcome the event-induced variances. Event induced variance occurs if the variance is under estimated, the test statistic will lead to the rejection of null hypothesis more frequently than it should, even when the average abnormal performance is zero (Brown and Warner, 1985). The results employing unadjusted abnormal returns and ordinary cross-sectional t-test will be subject to the event-induced variance (Balachandran, Cadle, and Theobald, 1999). The model to calculate SCST as follows:

$\mathrm{AR}_{\mathrm{t}} / \mathrm{SERR}(\mathrm{AR})$ est

(Model 4)

Where:

$\mathrm{AR}_{\mathrm{t}} \quad=$ Abnormal returns generated from market model for specified time period

SERR (AR) est $\quad=$ Standard error of the estimation period daily return

\section{T-test for Difference Mean for Two Independent Samples}

Parametric t-test is conducted to compare the means of two independent samples. This test is under assumption that the sample is normally distributed.

\section{Non-parametric test}

Non-parametric test, Mann-Whitney test, is also conducted to compare the median of two independent samples. The underlined assumption of this test is that the two distributions have the same shape, although the shape does not have to be normal.

\section{RESULTS AND DISCUSSIONS}

The results provide several importance findings that the existence of the market reaction is indicated by the increase in share prices relative to the announcement of pure executive option grants and the decrease in share price for the announcement of executive option announced simultaneously with the increase in directors' fees. 


\section{Market Reaction}

Price changes represented by abnormal returns are the best indicator to observe the market reaction around the announcement date of executive option grants. Table 1 reports the abnormal return generated from the market model for the full samples, pure executive option grants and executive options with directors' fees sample. This table provides the information related to the mean and median of abnormal returns, and standardised cross-sectional t-test. The average abnormal returns for 130 sample firms all are positive. Particularly for pre announcement period (day-60 to -2 ), the average abnormal return is $4.29 \%$ that statistically significant at the $10 \%$ level.

After splitting into two groups, the average abnormal return is $1.27 \%$ for pure executive option, which is significant at the $5 \%$ level for three days event window (from day -1 to day +1 ). The result provides evidence for hypothesis 1 that the market reacts positively to the announcement of executive option grants. Positive reaction is represented with the increase in share price during the event window that indicates that market perceives executive option grant announcements deliver favourable news. The market believes option grants motivate executive to increase the company's performance, because executive has incentives to work harder and will be rewarded for a good performance. As it is suggested in agency theory, the compensation package including share options should become an efficient tool to align executive-shareholders interest. Positive reactions are also found in the event window of day -60 to day -2 (the average mean is $6.76 \%$ ) and day -60 and day -3 (the average mean is $6.62 \%$ ). Both results are significant at the $5 \%$ levels.

In comparison, table 1 also reports negative market reaction for executive options that announced simultaneously with the increase in directors' fees. The average abnormal return is $-1.46 \%$ for executive options with the increase in directors' fees, which is significant at the $5 \%$ level for event window day -1 to day +1 . The result gives the indication that market is sensitive with the information considered as unfavourable news. The market negatively views the increase in the directors' fees since it will boost the fixed costs of the company and can reduce the profits. It denotes that market is not seeing the executive 
option grants as commensurate with performance and firm has to allocate another expense despite of share option compensations.

The findings for Australian firms are different with previous studies in the US, which find negative reaction prior to the announcement and positive reaction after the announcement of executive option grants. Positive reaction prior to the announcement of executive option grants for pure executive option group leads to the notion that there is no opportunistic behaviour to time the release of favourable news and unfavourable news around the announcement date.

Further, the parametric test results show that pure executive options group is different from executive options with directors' fees group. The result is statistically significant at least at $10 \%$ level for all events reported.

Table 1.

Market Reaction to Executive Share Option Announcement for All Samples

\begin{tabular}{|c|c|c|c|c|c|c|c|}
\hline & Mode & & $\begin{array}{c}\text { Full } \\
\text { Samples }\end{array}$ & $\begin{array}{c}\text { Pure } \\
\text { Executive } \\
\text { option }\end{array}$ & $\begin{array}{c}\text { Executive } \\
\text { option with } \\
\text { directors' fees }\end{array}$ & T-test & $\begin{array}{c}\text { Man- } \\
\text { Whitne } \\
\text { y Test }\end{array}$ \\
\hline $\begin{array}{l}\text { Day 0 to } \\
\text { day } 1\end{array}$ & $\mathrm{MM}$ & $\begin{array}{l}\text { Mean (\%) } \\
\text { Median (\%) } \\
\text { SCST }\end{array}$ & $\begin{array}{c}0.44 \\
0.07 \\
(-0.51) \\
\end{array}$ & $\begin{array}{c}1.14 \\
0.65 \\
(1.95)^{*} \\
\end{array}$ & $\begin{array}{c}-1.24 \\
-0.55 \\
(-1.55) \\
\end{array}$ & $2.71^{* * *}$ & $2.15^{\star *}$ \\
\hline $\begin{array}{l}\text { Day }-1 \\
\text { to day } 1\end{array}$ & $\mathrm{MM}$ & $\begin{array}{l}\text { Mean (\%) } \\
\text { Median (\%) } \\
\text { SCST }\end{array}$ & $\begin{array}{l}0.47 \\
-0.05 \\
(0.43) \\
\end{array}$ & $\begin{array}{c}1.27 \\
0.22 \\
(2.07)^{* *}\end{array}$ & $\begin{array}{c}-1.46 \\
-0.79 \\
(-1.97)^{* *}\end{array}$ & $2.92^{* * *}$ & $2.35^{* *}$ \\
\hline $\begin{array}{l}\text { Day }-2 \\
\text { to day } 2\end{array}$ & $\mathrm{MM}$ & $\begin{array}{l}\text { Mean (\%) } \\
\text { Median (\%) } \\
\text { SCST }\end{array}$ & $\begin{array}{c}0.53 \\
0.26 \\
(0.46) \\
\end{array}$ & $\begin{array}{c}1.20 \\
0.48 \\
(1.94)^{*} \\
\end{array}$ & $\begin{array}{r}-1.11 \\
-4.03 \\
(-1.60) \\
\end{array}$ & $2.10^{* *}$ & $1.72^{*}$ \\
\hline $\begin{array}{l}\text { Day }-60 \\
\text { to day - } \\
2\end{array}$ & $\mathrm{MM}$ & $\begin{array}{l}\text { Mean (\%) } \\
\text { Median (\%) } \\
\text { SCST }\end{array}$ & $\begin{array}{c}4.29 \\
1.65 \\
(1.72)^{*}\end{array}$ & $\begin{array}{c}6.76 \\
5.83 \\
(2.55)^{* *}\end{array}$ & $\begin{array}{r}-1.70 \\
-4.03 \\
(-0.51) \\
\end{array}$ & $1.62^{*}$ & $2.29 * *$ \\
\hline $\begin{array}{l}\text { Day }-60 \\
\text { to day - } \\
3\end{array}$ & MM & $\begin{array}{l}\text { Mean (\%) } \\
\text { Median (\%) } \\
\text { SCST }\end{array}$ & $\begin{array}{r}4.07 \\
2.30 \\
(1.60) \\
\end{array}$ & $\begin{array}{c}6.62 \\
5.60 \\
(2.44)^{* *} \\
\end{array}$ & $\begin{array}{r}-2.11 \\
-4.29 \\
(-0.62) \\
\end{array}$ & $1.67^{*}$ & $2.28^{* *}$ \\
\hline Sampl & ize & & 130 & 92 & 38 & & \\
\hline
\end{tabular}


Using two tail test:

$* * *$ Significant at the level $1 \%$

** Significant at the level 5\%

* Significant at the level $10 \%$

MM Market Model

SCST Standardised crosssectional t- test
Day 0 The

announcement day

Day 1 One day after the announcement

Day 2 Two days after the announcement Day -1 One day before the announcement Day -2 Two days before the announcement

Day -3 Three days before the announcement

Day -60 Sixty days before the announcement

To support the previous analysis, Figure 1 illustrates the difference in the market reaction between the announcement of pure executive option grant and the announcement of executive option grant with the increase in director's fees.

Figure 1.

CAR for Pure Executive Option Grants Versus Executive Option Grants with an Increase in Directors' Fees Groups (Day -60 to +60 )

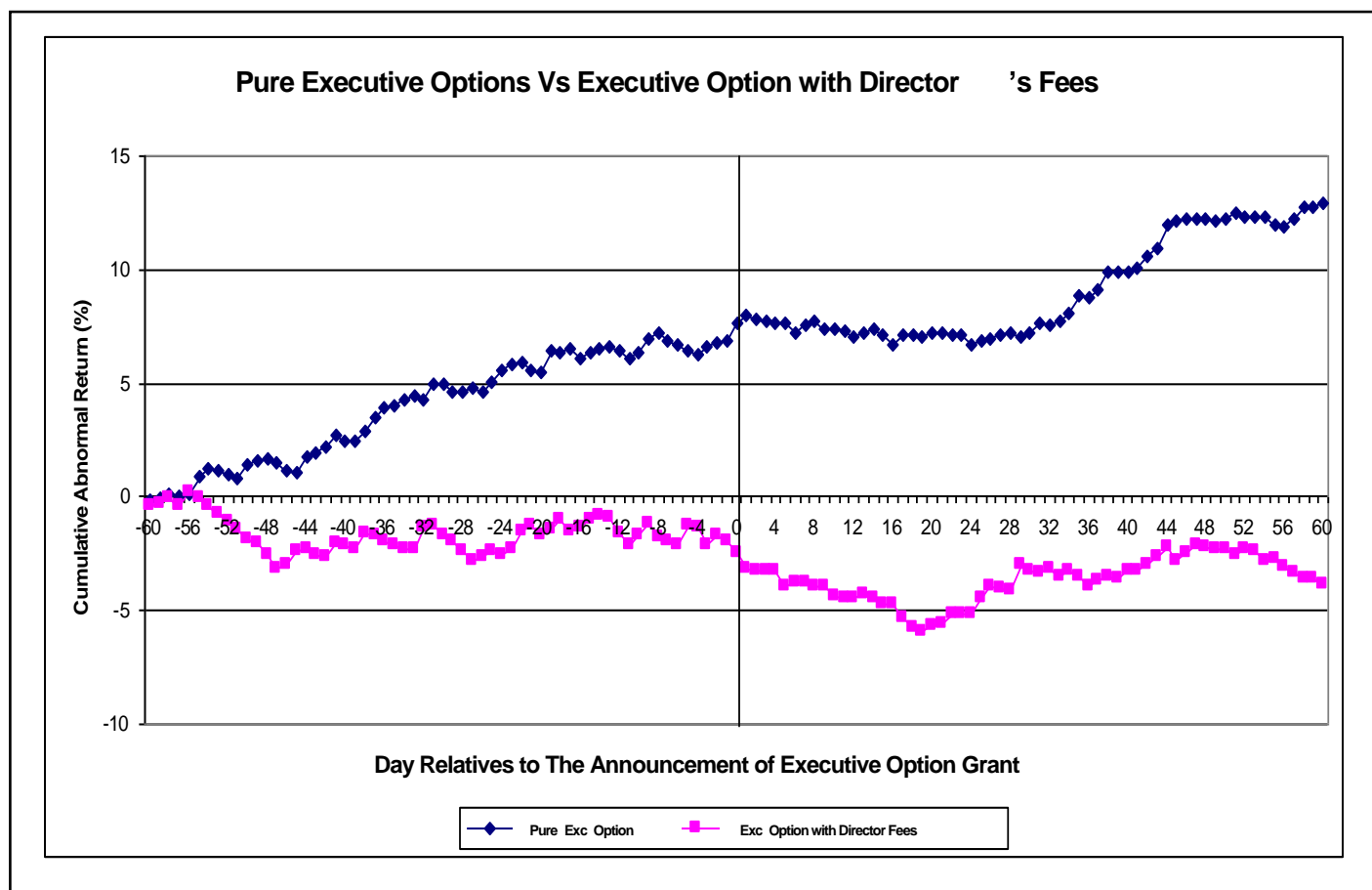

The figure illustrates that pure Executive option grants trigger positive market reactions from 60 days before the announcement date to 60 days afterward. The reaction is concentrated at the three days event window (day -1 
to day +1) and continues to increase after that until 60 days after the announcement date.

On the other hand, Figure 2 also indicates that the announcement of executive option grants concurrently with an increase in directors' fees generates a negative reaction. The reaction is concentrated at the event window day -1 to day +1 and continues to show a downward trend after the announcement date (day 0).

Similarly, Figure 2 gives clear illustration the difference between two groups market reaction for event period twenty days before the announcements to twenty days after the announcements of executive option grants. The market reaction for both groups is concentrated at day -1 to day +1 .

Figure 2.

CAR for Pure Executive Option Grants Versus Executive Option Grants with an Increase in Directors' Fees Groups (Day -20 to +20 )

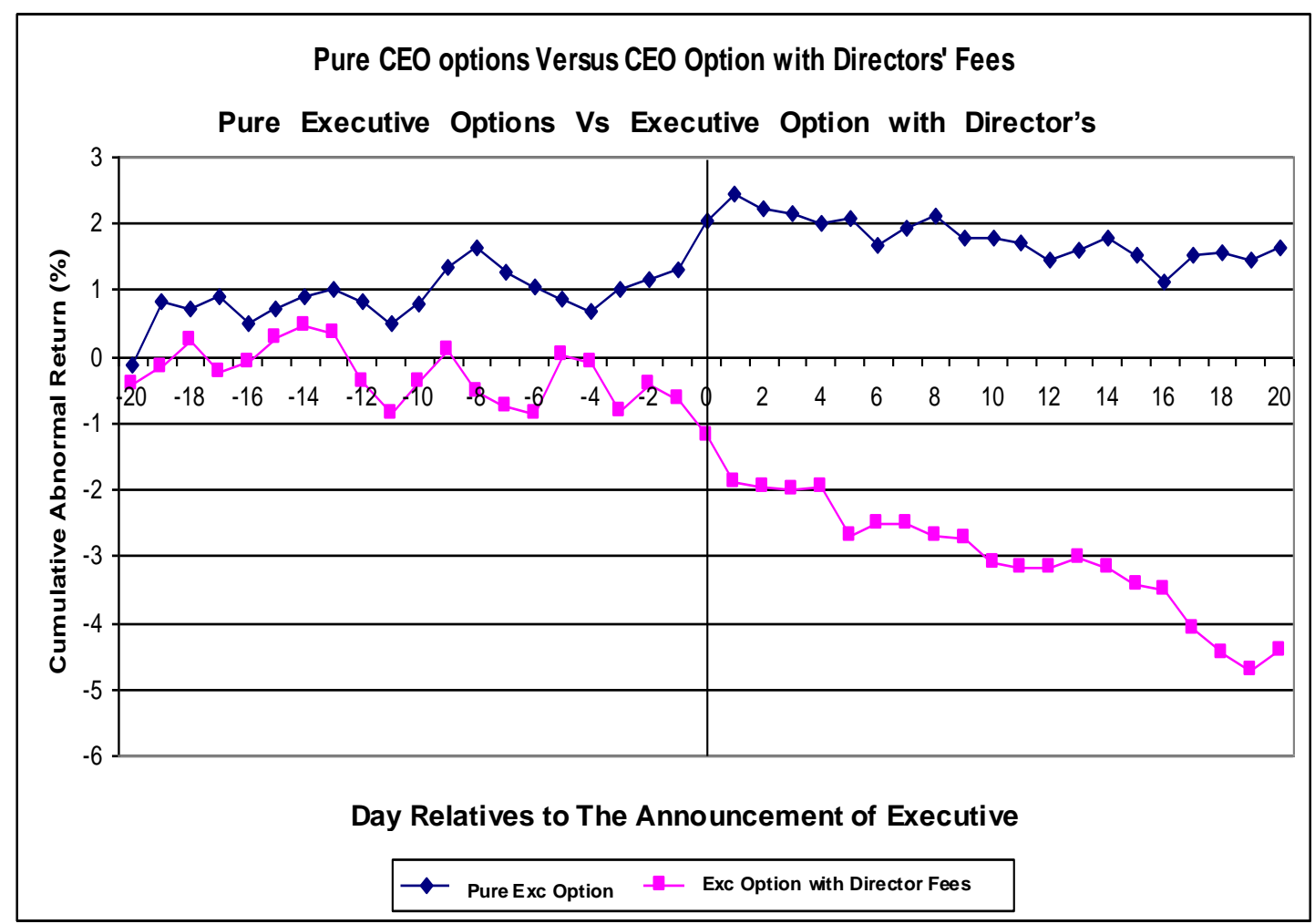

The upward trend of share prices of pure executive options group before and after announcements in both figures denote there is no opportunistic behaviour to time of releasing of good news and bad news in Australian 
evidence. It indicates that share options grants can align the interest between executive and shareholders.

Only in the pre announcement period the result differs from previous studying, which mostly find negative abnormal returns before the announcement date and positive abnormal returns after the announcement date. Previous study documented that mixed results associated to the announcement of executive option grants indicated executive timed the release of good news and bad news.

The Existence of Performance Hurdles

Performance hurdles attached to option grants give assurance that the vesting of executive options will not occur unless the hurdles are achieved. If only the existence of performance hurdles attached to the grant would be insufficient. The performance hurdles must be effective, which is including the magnitude of performance hurdles. Adequate performance hurdles ensure that the increase of share price is as the result of management efforts rather than the result of overall economy (Brickley, Bhagat and Lease, 1985).

Table 2 shows that the majority of the firms have

performance hurdles $(85 \%)$ attached to the grants.

Findings from Australian evidence indicate that the

granting of executive options grants mostly have

performance hurdles. Under the current regulation, if

the company decides to grant executive options

without performance hurdles attached to the grant,

they have to disclose the reasons why they do not set

the performance benchmark. The findings show that 


\section{the type of performance hurdles used by the firms}

\section{generally is total shareholders return $(38 \%)$, share \\ price hurdles $(26 \%)$, and earning per share $(8 \%)$.}

This study also reports that for the sub sample of firms only granting executive options, $86 \%$ of the firms have performance hurdles attached. The contender group, sub sample of firms granting executive option and having an increase in directors' fees, $82 \%$ of the firms have performance hurdles.

Both groups have a tendency to use the same type of performance hurdles such as total shareholder return, share price hurdles, earning per share or return on equity. The results presented in Table 2 indicate that the existence of performance hurdles is common in Australia and most of executive option grant are subject to performance hurdles.

Table 2.

Performance Hurdles

\section{All samples}

Performance Hurdles

\begin{tabular}{|c|c|c|c|c|}
\hline Total & $\%$ & $\begin{array}{l}\text { Type of } \\
\text { Hurdles }\end{array}$ & Total & $\%$ \\
\hline 110 & 85 & Total Shareholder Return & 42 & 38 \\
\hline 20 & 15 & Share Price & 29 & 26 \\
\hline 130 & & Earning per share & 9 & 8 \\
\hline & & Return on Equity & 6 & 5 \\
\hline & & & 24 & 22 \\
\hline & & & 110 & \\
\hline
\end{tabular}

Pure Executive option samples

Performance Hurdles

\begin{tabular}{|c|c|c|c|c|}
\hline Total & $\%$ & $\begin{array}{l}\text { Type of } \\
\text { Hurdles }\end{array}$ & Total & $\%$ \\
\hline 79 & 86 & Total Shareholder Return & 26 & 33 \\
\hline 13 & 14 & Share Price & 22 & 38 \\
\hline 92 & & Earning per share & 7 & 9 \\
\hline & & Return on Equity & 4 & 5 \\
\hline & & \multirow[t]{2}{*}{ Others* } & 20 & 25 \\
\hline & & & 79 & \\
\hline
\end{tabular}

CEO option with directors'

fees samples 


\begin{tabular}{|c|c|c|c|c|c|}
\hline & Total & $\%$ & $\begin{array}{l}\text { Type of Performa } \\
\text { Hurdles }\end{array}$ & Total & $\%$ \\
\hline Performance Hurdles & 31 & $\overline{82}$ & Total Shareholder Return & 16 & 52 \\
\hline \multirow[t]{5}{*}{ No Performance Hurdles } & 7 & 18 & Share Price & 7 & 23 \\
\hline & 38 & & Earning per share & 2 & \\
\hline & & & Return on Equity & 2 & 6 \\
\hline & & & Others* & 4 & 1 \\
\hline & & & & 31 & \\
\hline
\end{tabular}

*Others include NPAT, NPBT, EBITA, Accumulation Index, Investment Growth, Market Capitalisation and Annual Compound Growth.

\section{Discussions and Limitations}

The purpose of granting executive options is to align managersshareholders interests. The existence of positive market reactions around the announcement dates indicates that market perceives the granting of executive with share options as favourable news. They believe that executive will work to increase the company's performance, which is consistent with the purpose of setting compensation packages as suggested in the agency theory. The findings strengthen argument that options are still popular means in aligning the interest between executive and shareholders.

The result is different from the US studies, which mostly found negative market reaction prior to the announcement of executive option grants and positive market reaction after the announcement dates. It may indicate that Australian executive may not use his discretion to manipulate the release of bad news and good news in determining exercise price.

Descriptive data of performance hurdles leads to the first notion that the existence of performance hurdles attached to the grants is prevalent in Australia. The measurement should include the magnitude of adequate performance hurdles, which might come in different results.

This study acknowledges the limitations regarding the time of study, small number of data and control variables. Data elimination that contaminated with other announcements has been used in this study to control the sample. However, there might be other variables, which affect the increase or decrease in share prices, which is beyond control of this study. 
Therefore, further research can be developed in many ways. First, it can look at the impact other contaminate news to the announcements executive option grants despite of the increase in directors fees such as issue shares. Second, it should measure the market reaction to the option grants by looking at the magnitude of adequate performance hurdles.

\section{CONCLUSION}

To sum up, measuring the effectiveness of share options as the means to solve the agency problems, which exists between managers and shareholders are very complex investigation. Many factors should consider giving difference perspective on the effectiveness of share option.

Overall findings from this study lead to the argument that share options are the effective means to align managers-shareholders interest, the existence of performance hurdles is prevalent in Australia, and most of executive option grant are subject to performance hurdles.

\section{REFERENCES}

Bergmann, G. (2003). Getting Your Fair Share, Australian CPA, Vol. 73, No. 8, pp. 78-79.

Brickley, J. A., S. Bhagat, and R. C. Lease (1985). The Impact of Long-range Managerial Compensation Plans on Shareholder Wealth, Journal of Accounting and Economics, 7, pp. 115-129.

Brookfield, D. and P. Ormrod (2000). Executive Stock Options: Volatility, Managerial Decisions and Agency Costs, Journal of Multinational financial Management, Vol. 10, pp. 275-295.

Brown, M. and Samson, D. (2003). Executive Compensation: Balancing Competing Priorities, Australian Accounting Review, Vol. 36, no. 3, pp. 316323.

Brown, P. and Yew, E. (2002). How Do Investors Regard ESOs? Australian Accounting Review, Vol. 12, no.1, pp. 36-42.

Buffini, F., and D. Kitney (2005). Executive Salaries: Plenty of Extras in CEOs' Pay Packets, The Australian Financial Review, 16 November 2005.

Cassano, M. (2003). Executive Stock Options: Back to Basics, The Australian Economic Review, vol.36, No.3, pp.306-315.

Chalmers, K. and P. Koh (2005). Value of Enforcement Regime Change: Option Value Disclosure, Working Paper, www.business.uq.edu.au/ events/speakers/kchalmers-paper.pdf, Date Accessed [21/11/2005].

Clark, K. (2004). Share and Share Alike, Australian CPA, Vol. 74, No. 4, pp. 72-76.

Colquhoun, L. (2001). Executive Options Under the Gun, Business Review Weekly, Vol. 23, Issue 18, p. 60-62. 
Core, J. E., R. W. Holthausen, and D. F. Larcker (1998). Corporate Governance, Chief Executive Officer Compensation, and Firm Performance, Journal of Economics, Vol. 51, pp. 371-406.

Coulton, J. and S. Taylor (2002). Option Awards for Australian CEOs: the Who, What and Why, Australian Accounting Review, Vol. 12, No. 1, pp. 25-35.

Goodwin, J. and P. Kent (2004). The Incentives of Australian Companies To Utilize Executive Stock Option Plans, Corporate Ownership $\mathcal{E}$ Control, Volume 1, Issue 2 (Winter), pp. 137-149.

Gordon, J. N. (2002). What Enron Means for the Management and Control of the Modern Business Corporation: Some Initial Reflection, The University of Chicago Law Review, Summer, 69, 3, pp. 1233-1250.

Griner, E. H. (1999). The Effect of CEO Option Grants on Shareholders Return, Journal of Managerial Issues, Vol. XI, No. 4, Winter (1999), pp. 427-439.

Hall, B. J. and K. J. Murphy (2002). Stock Options for Undiversified Executives, Journal of Accounting and Economics, 33, pp. 3-42.

Hooper, N. (2005). Long-term Incentives the Way to Go, The Australian Financial Review, 16 November 2005.

Jensen, M. C. and K. J. Murphy (1990). Performance Pay and Top-Management Incentives, Journal of Political Economy, Vol. 98, No. 21, pp. 225-264.

Jensen, M.C. and Meckling, W.H. (1976). Theory of the Firms: Managerial Behaviour, the Agency Costs and the Ownership Structure, Journal of Financial Economics, Vol.3, pp. 305-360.

Kerin, P. (2003). Executive Compensation: Getting the Mix Right, The Australian Economic Review, Vol. 36, No. 3, pp. 324-332.

Lie. E., (2005). On the Timing of CEO Stock Option Awards, Management Science, Vol. 51, No. 5., pp. 802-812.

Martin, K. J. and R. S. Thomas (2003). When is Enough, Enough? Market Reaction to Highly Dilutive Stock Option Plans and the Subsequent Impact on CEO Compensation, Journal of Corporate Finance, XX, pp. 1-23.

Morgan, P. and A. B. Poulsen (2001). Linking Pay to Performance-Compensation Proposals in the S\&P 500, Journal of financial Economics, Vol. 62, pp. 489-523.

Nofsinger, J. R. and B. Prucyk (2003). Option Volume and Volatility Response to Scheduled Economic News Releases, The Journal of Future Markets, 23, 4, pp. 315-345.

SPSS Base 7.0 Application Guide (1996). SPSS Inc.

Stoddart, E. K. (2001). Options in Valuing Equity Compensation Benefits, Australian Accounting Review, Vol. 11, No. 2, pp. 49-61.

Thomson, J. (2002). Value for Money, Business Review Weekly, 20/12/20019/1/2002, pp.71-73.

Yermack, D. (1997). Good Timing: CEO Stock Option Awards and Company News Announcements, The Journal of Finance, Vol. LII, No. 2, pp. 449-476. 